\title{
Mangongkal Holi Tradition as an Alternative Solution to the Lack of Cemetery Land in Indonesia
}

\author{
Charles David Silalahi ${ }^{1}$, Robert Sibarani ${ }^{2}$, Eddy Setia $^{3}$, M.Takkari ${ }^{4}$ \\ $\left\{\right.$ lie.chuck.dave@gmail.com ${ }^{1}$, rs_sibarani@yahoo.com ${ }^{2}$, eddy12457@yahoo.com², \\ mtakari@yahoo.com ${ }^{4}$ \} \\ University of Sumatera Utara ${ }^{1234}$
}

\begin{abstract}
This is a result of a qualitative, direct participatory research done by the researchers, as a part of the first writer's Dissertation entitled Tradisi Mangongkal Holi pada Masyarakat Batak Toba. Mangongkal Holi is known as a series of ancient rituals which excavating/replacing ancestors' saring-saring from underground/basement cemetary/tambak to a new place called batu na pir/tambak na timbo as an effort in uplifting their social status in the society. In meantime, the numbers of the dead-men cannot be avoided, and the government needs larger cemetery land time to time. The data were collected through direct participatory observation, in-depth interviews with many batak toba informants (adat's experts, practitioners) as well as audio-visual documentation. The data were analyzed by using Miles, and Huberman models (2014:8), where data condensation, data display and drawing conclusion/verification were the three concurrent flows activities done to make sure the process of data analysis precisely on the track. The final conclusion is the government as well as the churches' congregation should preserve the mangongkal holi tradition as an alternative solution for the lackness of the cemetery land, since the ex-tomb could be re-used for the others dead-men. On the other hand, Rumah Saring-Saring as well as great/giant tambak/tugu should be consider as a problem solving for the needs of cemetery land in the future.
\end{abstract}

Keywords: Mangongkal Holi, Anthropolinguistics, Cemetery Land, Oral tradition Rumah Saring-saring,.

\section{Introduction}

Mangongkal Holi is a series of excavating respected ancestors' saring-saring/bones; then replaced it into $2^{\text {nd }}$ or $3^{\text {rd }}$ floor of tambak na timbo/batu na pir, or man made stone grave. Since mangongkal holi is the highest level of traditional ceremony, it should be arranged with a good preparation (Silalahi, 2016:1). Hasuhuton bolon family should plan and organize it at least six month before the rituals done. As the host, hasuhuton bolon should meet and communicate all of the plan with their dongan tubu, boru/bere/ibebere, each of hula-hula's elements, adat's practitioners as well as the pastor/priest as an inter-connected parties.

This tradition is held in order to show the descendents' respect to their Hula-Hula's families as well as a thanksgiving devotion to God for all the good things received by the descendents' families. Nowadays, this oral tradition is acknowledged as a rare ritual done by the Batak Toba societies. Since it is still classified as a family responsibility (funding, organizing) and it needs a long terms preparation; so, that is why, this oral tradition could be rared to find in the society. 
In general, deadbody/corpse's funeral activity, is burried underground; it means government should alocate more cemetery land to receive all the deadmen. In the big cities, this condition has become a serious problem for the lackness/limited of cemetery land. In Medan for instance, Simalingkar B cemetery land receives 7-10 deadmen daily; it equals to $20.000 \mathrm{~m}$ cemetery land per year. Furthermore, in Jakarta the limited of the cemetery land force the family to burry their family in levels (one hole consists of 2-4 deadmen), and still this is just a temporarily solution, but it will not able to solve the main problem and for sure the family should be able to find a better and real solution in the future. Since the number of land is constant but the needs of cemetery land increasing day by day, this condition will lead a serious conflict between deadmen vs livemen in the future. What will be happened in the next 50 years? or even in the next 100 years?

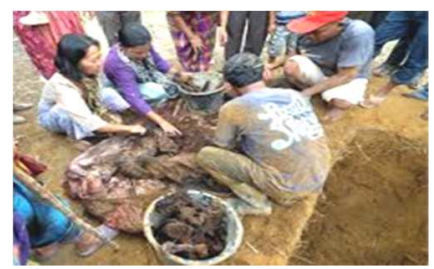

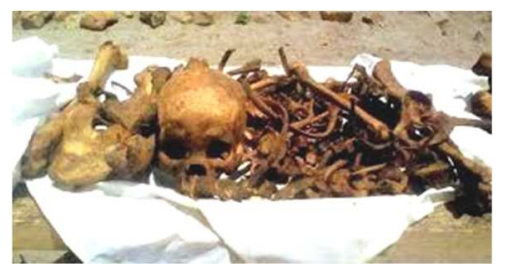

Fig. 1, 2, 3.

(2) Drying the saring-saring; (3) Batu na Pir [multi-levels stone-graves]

\section{Research Method}

In order to collect the data of the research, the researcher do a field research through a direct participant observatory; where the researcher attended the traditional events both on Mangongkal Holi in Sarimatondang village, Sidamanik regency, Simalungun District, and in Salaon Dolok village, Ronggur ni Huta regency, Samosir District. Furthermore, the researcher did in-depth and open-ended interview to obtain the more complete data research from the informants. The data were analyzed based on Anthropolinguistics, while the performance will be used to discuss those text, co-text and context and indexicality will be used to discuss the value, norms, means of local wisdom found in mangongkal holi tradition.

Miles and Huberman model (2014:8) says, there are three concurrent steps that every qualitative researcher in analyzing the data: data condensation, data display, and conclusion/verification, as shown below:

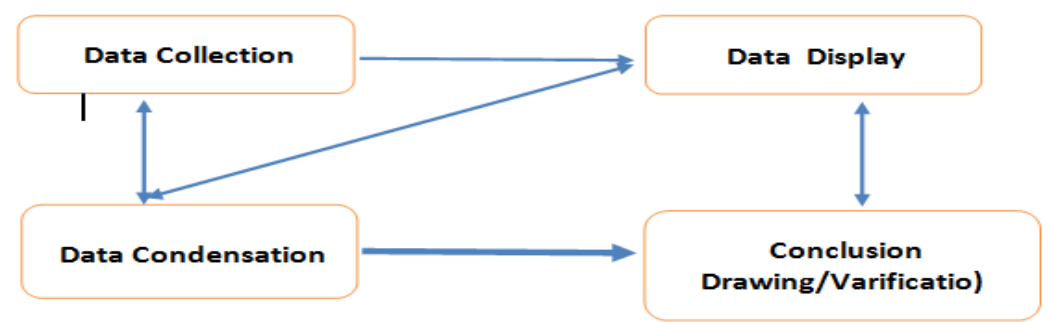

Fig. 2. Miles and Huberman (2014:8) Data Analysis Model 


\section{Discussions}

In 2018, Indonesian Statistics department (BPS) stated that in 2017, the total of Indonesian population is 261,7 million people; and in 2015 BPS noted that Batak society was one of the biggest communities in Indonesia. It was said that there were 8,466,969 people (for sure the amount will be increased nowadays, 2015-2019). If this numbers is devided into 5 sub-batak ethnics (Tobanese, Simalungunese, Karonese, Mandailing, Angkola) equally, there were 1.693.393 Tobanese people in Indonesia, and it is not the total number of Batak Toba people in the world.

This fact indicates and predicts that the needs of cemetery land is highly needed, since not only Batak Toba people who need the cemetery land to burry/plant their dead family but also, most of the community in Indonesia or even in the world. Only a few of group people who did not do the same things (cremation funeral for Budhist/Hindist). If there are 100 people died/day, it means, government needs $100 \times\left[2 \times 1\right.$ metre $\left.^{2}\right]=200$ metres $^{2}=0.2$ Hectare, and if it is counted in a year, the government should prepare 365 days x 0.2 hectare $=73$ hectares/year. of course it is a great amount of cemetery land. This condition will hazard the needs of human agriculture to fulfill the live men, as well as their needs for houses. On this condition, the conflict between the dead-men vs live-men will be increasing seriously.

\subsection{Mangongkal Holi Steps and Procedures}

Mangongkal holi tradition consists of a series of ritual/traditional activities: tonggo raja, mangongkal holi/paumbanghon saring-saring, panangkokhon saring-saring tu batu na pir, sulang bao, mangaliat horbo, mambuat tua ni gondang, pesta adat na gok, and mangampu.

Table 1. Mangongkal Holi Steps and Procedures.

\begin{tabular}{|c|c|c|}
\hline No. & $\begin{array}{l}\text { Steps of Mangongkal } \\
\text { Holi }\end{array}$ & Description \\
\hline 1 & $\begin{array}{l}\text { Tonggo Raja (Royal } \\
\text { Meeting) }\end{array}$ & $\begin{array}{l}\text { A meeting attended by hasuhuton bolon (as a host) and } \\
\text { paidua ni suhut (as hasuhuton bolon's spokesperson), } \\
\text { hula-hula's dongan tubu (brother or the same sirname), } \\
\text { hula-hula's boru (sisters' family or aunts'family) every } \\
\text { hula-hula families (tulang, hula-hula/simatua, bona } \\
\text { tulang, tulang robobot, bona ni ari, hula-hula } \\
\text { namarhahaanggi, hula-hula naposo), and raja dongan ni } \\
\text { huta (neighbourhood in Adat) which functioned as } \\
\text { delivering proposal to held mangongkal holi tradition for } \\
\text { their respected parents. }\end{array}$ \\
\hline 2 & $\begin{array}{l}\text { Mangongkal } \\
\text { Holi/Paumbanghon } \\
\text { Saring-Saring, }\end{array}$ & $\begin{array}{l}\text { Replacing/removing the saring-saring (bones/ skeleton) } \\
\text { from the tomb/tambak. }\end{array}$ \\
\hline 3 & $\begin{array}{l}\text { Panangkokhon } \\
\text { Saring-Saring tu Batu } \\
\text { na Pir, }\end{array}$ & $\begin{array}{l}\text { Uplifting/upgrading the position of the saring-saring to } \\
\text { batu na pa pir (to the higher level of tambak) }\end{array}$ \\
\hline 4 & Sulang Bao & $\begin{array}{l}\text { Delivering thanksgiving expression toward hula-hula's } \\
\text { participation (especially tulang and hula-hula/simatua) on } \\
\text { the previous rituals with turi-turi sipanganon and money. }\end{array}$ \\
\hline
\end{tabular}




\begin{tabular}{|c|c|c|}
\hline No. & $\begin{array}{c}\text { Steps of Mangongkal } \\
\text { Holi }\end{array}$ & Description \\
\hline 5 & Mangaliat Horbo & $\begin{array}{l}\text { Speaking to their ancestors' sahala (spirit), through the } \\
\text { sacrifying of horbo sitikko tanduk (water bufalo). It is a } \\
\text { permitting/begging session, hope their ancestor will be } \\
\text { happy to receive the sacrifation, and the sahala will } \\
\text { protect and lead their descendants in doing the pesta adat } \\
\text { na gok. }\end{array}$ \\
\hline 6 & $\begin{array}{l}\text { Mambuat Tua ni } \\
\text { Gondang }\end{array}$ & $\begin{array}{l}\text { Opening/Starting the gondang sabangunan officially. It } \\
\text { was opening by the pangula ni huria (pastor, priest), } \\
\text { afterwards hasuhuton bolon together with each of the } \\
\text { group of hula-hula, dongan sahuta can manortor } \\
\text { (dance). }\end{array}$ \\
\hline 7 & Pesta Adat na Gok & $\begin{array}{l}\text { Big party: receiving the groups of hula-hula delivering } \\
\text { their adat's presents; boras si pir ni tondi/eme na lundu } \\
\text { (rice/paddy), ulos siganjang rambu, and pasu-pasu } \\
\text { (blessing words) }\end{array}$ \\
\hline 8 & Mangampu & $\begin{array}{l}\text { Expressing thanksfulness to all of the audience who } \\
\text { attend the whole steps of the mangongkal holi tradition. }\end{array}$ \\
\hline
\end{tabular}

\subsection{Mangongkal Holi/Mangumbanghon Saring-Saring and Panangkokhon Saring-Saring tu Batu na Pir}

Mangongkal holi or mangumbanghon saring-saring is a process of excavating someone's saring-saring (bones/skeleton) underground, then clean them and replace them into batu na pir $\left(2^{\text {nd }}\right.$ or $3^{\text {rd }}$ level/floor of tambak/tugu). Mangumbanghon means to make the saring-saring floating. The procedures of this ritual started when pangula ni huria lead a Christian services followed by all the audience. On this services, the pastor/priest will lead the audience, especially the hasuhuton bolon (host) in remembering the God's gospel; respecting parents, following God's laws/instructions in preserving the good cultures in society. At the end of the services, the pastor/priest simbolically excavate the cemetery by digging the soil 3 times, then over the hoe to hasuhuton bolon and do the same thing. If there are more than one tombs that will be replaced, so the pastor/priest, and members of hasuhuton bolon will do the same thing to the tombs.

Further, hasuhuton bolon will hand-over the process of excavating the saring-saring to boru/bere/ibebere (Sisters', nieces'/nephews' family) male teams to complete the excavating process. In meantime, the hasuhuton bolon's paniaran (wife) will throw money to the hole, as an effort to motivate them. And as the coffin have been seen, boru sihabolonan will yield Horas.. Horas.. Horas and spread boras na pir (rice) to the air next to the hole(s). After the cap of the coffin removed, later on Boru will get the head and jaws then give it to hasuhuton bolon.

Next, hasuhuton bolon will pass the saring-saring to tulang family on their ulos panampin (white cloth), this is called as 'manampin' process; afterwards, the saring-saring will be given to hasuhuton boru's boru/bere/ibebere (Sisters', nieces'/nephews' family) female teams to clean the saring-saring. Cleaning process including: washing the saring-saring by using clean and fresh water, then pouring the essence of tumeric to the whole part of the saring-saring and dried them.

After the saring-saring dried, furthermore it was devided into two parts: skull + jaw is placed in normal position on a white plate and skeleton are place in a common position wrapped 
by an ulos panampin. Those parts are placed on a table as the final preparation to the next ritual called, panangkokhon saring-saring tu batu na pir. This ritual is lead by the same pangula ni huria, it is started when both panampin give ulos laman-laman (ulos Bolean) on the skulls, furthermore paidua ni suhut hand over the steps to pangula ni huria, he will holify the elements include in the process; the hasuhuton bolon family members, the saring-saring, batu na pir and gondang sabangunan.

Next, panampin will lay the skulls on the top of panghunti (female boru sihabolonan and/or boru suhut bolon who put the skull and skeleton on their head) and pass it to hasuhuton bolon; who have been waiting at the $2^{\text {nd }}$ level of tambak, and hasuhuton bolon take the skull as well as the skeleton to be placed on batu na pir (smaller room on the $2^{\text {nd }}$ floor of tambak). Finally hasuhuton bolon placed the essence of unte pangir (nubbled lime) in the middle of the skulls and napuran (material for betel's chew) in front of the skulls/skeleton.

After all the process of mangongkal holi and panangkokhon saring-saring tu batu na pir is accomplished, male boru/bere/ibebere closed the hole of the tomb and plant a banana tree in the middle of it. This is as an indicator that the tomb was empty, and it could be reused by the other family to bury their dead family. On the other hand, the sign of planting banana's tree/shoot, informing indirectly to the extended families that the tomb was empty, the corpse had been removed to the other place, so they do not need to have devotional visit/services on the tomb.

\subsection{Mangongkal Holi: as an alternative solution of the lackness of cemetery land needs}

As the writer mentioned above, the needs of cemetery is very important because everyday there must be new born babies as well as died men, while mostly the died men were burried underground, and only a few of community decided themselves to be burned in creamatorium sites. The problem started when some of the cemetery lands area were full, it means the government should find new location of cemetery land. In some area, a few businessman found that this condition has been potentially becoming a good and bright income. They prepare big, great cemetery land with a lot of services, eventhough the customer should pay expensive rates for that; and for sure only a few of people will be able to use the cemetery land.

As a good information, some of the big clan of Batak Toba's ancestors have thought this generously. They have built many tambak na timbo/batu na pir (multi-level stone grave) on their own land; these fact could be easily found when people travel to Balige and Samosir, while there are so many tambak/tugu along side of the main street. This tambak could save many coffins as well as the saring-saring in it.

Furthermore, in the late of 10 years there were at least two big memorable ideas shown up, namely: Rumah Saring-Saring in the ex-cemetery land of St. Fransiskus Asisi, Pematangsiantar and Tambak Marga Manihuruk, in Pangururan, Samosir. Rumah Saring-Saring is realized as the solution of the lackness of cemetery land, especially for the congregation member of the church. Since the church had been built 40 years ago, they only have about $5000 \mathrm{~m}^{2}$ wide for their cemetery land, and it had full soon in the next 20 years. So, the next died congregation must be burried in the other cemetery land which location was outside the church's cemetery land.

This condition happened until 2008, when a new Pastor initiate the idea of building Rumah Saring-Saring (the house of skulls and skeletons) in the area of old cemetery land. They found a committee to construct the building, and excavate all the saring-saring in the cemetery land, and removed the saring-saring to the new building, where each family will have a slot of 'batu na pir' in the in the rumah saring-saring. The Pastor offers the services of Christianity 
sacrament services as commonly found in the rituals of mangongkal holi. When the cemetery land has an empty space, in meantime the dead body could be burried in the ex-tomb.

Furthermore, the committee has been building 20 slots for decomposition corpse in the basement of the building $2 \times 1 \mathrm{~m}^{2}$ for each coffin. Nowadays, they have prepared a certain regulation for all of the congregation members: when the corpse has been 8 years, the family must replace the saring-saring of their family member to Rumah Saring-Saring. So, the need of decomposition corpses' slot will be available continously.

Recently, they have built half (left side) of the cemetery land area, and they plan to build another side of cemetery land. The Pastor feel optimist if the rumah saring-saring, as well as the composition corpse could be built soon, they will not afraid to the lackness of cemetery land up to 100 year in the future.

Tambak Marga Simanihuruk was build after the death of General Manihuruk. The tambak was build uniquely, adopting the construction of honey bee's house. The area of the tambak just aroud $1500 \mathrm{~m}^{2}$, but the tambak has prepared 24 decomposition corpse, and 700's saring-saring slots.

\subsection{Local Wisdom found in Mangongkal Holi Tradition}

There are six local wisdom found in mangongkal holi tradition, they are: thanksgiving, respecting, responsibility, mutul cooperation, concensus in dialogues, and prestige. Those local wisdom were arisen from this analytical table:

Table 2. Textual Analysis for the Local Wisdom expression

\begin{tabular}{|c|c|c|c|}
\hline No. & Texts & Meaning & Analysis \\
\hline 1 & $\begin{array}{l}\text { Tuhan Debata namaringanan } \\
\text { dibanua ginjang, tong-tong do } \\
\text { mandok mauliate hami tu Ho } \\
\text { di siala di iring-iringi jala di } \\
\text { dongani Ho hami ale Tuhan... } \\
\text { boi hami marpungu di alaman } \\
\text { jabu ni amangboru nami on } \\
\text { ima pinompar ni amangboru } \\
\text { nami na lao pasangaphon } \\
\text { natua-tua na, sude na i ale } \\
\text { Tuhan dang alani gogo nasida } \\
\text { Alana na pasu-pasu sian ho i } \\
\text { do ale Tuhan }\end{array}$ & $\begin{array}{l}\text { Our Heavely God, we always } \\
\text { say thanks to You for Your } \\
\text { accompanion toward us.. We } \\
\text { can gather here in front yard of } \\
\text { the host's house which is the } \\
\text { decendant of our respected } \\
\text { 'perents'. It's not because of } \\
\text { their strength, but it's all } \\
\text { because of Your blessing. }\end{array}$ & $\begin{array}{l}\text { Thanksgiving and } \\
\text { respecting expressios, } \\
\text { realizing that anything in our } \\
\text { life is because of God's love. } \\
\text { Respecting parents is the } \\
\text { manifestation of respecting } \\
\text { God. Before doing anything, } \\
\text { please express your } \\
\text { thanksfulness to God as the } \\
\text { Almighty. }\end{array}$ \\
\hline 2 & $\begin{array}{l}\text { Tarlumobi ma tu tulang } \\
\text { Sidabutar tar suang songoni } \\
\text { ma tu Simatua Nainggolan asa } \\
\text { bersiap-siap hamu amang } \\
\text { panampin... jadi parjolo ma } \\
\text { jolo boru patiur-tiur hon on } \\
\text { sampe tarida saring-saring i } \\
\text { dah, jala masuk ma anak } \\
\text { siangkaan tu bagas, ingkon } \\
\text { hamu do sian ginjang ulu i } \\
\text { bulat sude tulang ma manjalo, } \\
\text { ima ruhut ruhut batak molo } \\
\text { mangongkal holi, molo dung }\end{array}$ & $\begin{array}{l}\text { For those Tulang Sidabutar as } \\
\text { well as Simatua Nainggolan, be } \\
\text { ready as the panampin. First, } \\
\text { Boru get into the hole, to open } \\
\text { the coffin until you can find } \\
\text { and see the saring-saring, later } \\
\text { the first son of hasuhuton bolon } \\
\text { get into the hole and take the } \\
\text { whole part of skull ( }+ \text { jaw) and } \\
\text { pass it over to tulang, that is the } \\
\text { rules of mangongkal holi } \\
\text { tradition, so please be ready. }\end{array}$ & $\begin{array}{l}\text { Responsibility and Mutual } \\
\text { cooperation are clearly seen } \\
\text { in this activity: natua-tua ni } \\
\text { huta guiding those } \\
\text { performers, } \\
\text { functioning as the saring- } \\
\text { saring cleanser and remover, } \\
\text { the first son of hasuhuton } \\
\text { bolon as the deliverer of } \\
\text { skull and jaws to tulang (as } \\
\text { the panampin). The rituals } \\
\text { could be done successfully } \\
\text { when they support one each }\end{array}$ \\
\hline
\end{tabular}




\begin{tabular}{|c|c|c|c|}
\hline No. & Texts & Meaning & Analysis \\
\hline & $\begin{array}{l}\text { di gali disi tarida ulu masuk } \\
\text { ma anak di angkat ma tu } \\
\text { ginjang manakke ma tulang di } \\
\text { ginjang, on pe naung songoni } \\
\text { on asa pintor siap-siap hian } \\
\text { hamu. }\end{array}$ & & $\begin{array}{l}\text { other. Every performer } \\
\text { must responsible to their } \\
\text { duties. }\end{array}$ \\
\hline 3 & $\begin{array}{l}\text { Jadi mauliate ma di } \\
\text { amangboru nami ala na olo do } \\
\text { hamu manjalo panuturion, na } \\
\text { hubege hami na dipatolhas } \\
\text { raja Sidabutar jolo di bungkus, } \\
\text { alai molo nasomal si } \\
\text { songonon di samosir } \\
\text { khususnya jolo bahenon ta do } \\
\text { palampin (laman-laman) ima } \\
\text { tu simanjujung ni namboru ta } \\
\text { on ipe di namarnamboru, } \\
\text { namarbere maripebere, dung } \\
\text { sikkop ma di lehon hita } \\
\text { panampin baru mundur hita, } \\
\text { berikut ma muse acara na lao } \\
\text { manungkun gondang ni } \\
\text { amangboru on, dos roha. }\end{array}$ & $\begin{array}{l}\text { So, thank you amangboru, } \\
\text { because you are pleased to } \\
\text { follow our guidance, as we hear } \\
\text { from tulang Sidabutar, the } \\
\text { saring-saring should be } \\
\text { wrapped, otherwise as we do in } \\
\text { Samosir, we have to lay the } \\
\text { ulos palampin (laman-laman) } \\
\text { on the head of panjujung } \\
\text { (boru/bere/ ibebere), then, } \\
\text { we'll step backward after we } \\
\text { give the ulos before requesting } \\
\text { the gondang, hope we will deal } \\
\text { with it. }\end{array}$ & $\begin{array}{l}\text { Concensus in dialogue } \\
\text { expression is clearly seen in } \\
\text { this context; when simatua } \\
\text { Nainggolan express their } \\
\text { intention in order to make } \\
\text { the ritual run on the right } \\
\text { track. They try to make an } \\
\text { overview, based on their } \\
\text { experience; and they ask an } \\
\text { affirmation toward the } \\
\text { statement. Concensus in } \\
\text { dialogue is good to be } \\
\text { developed and maintained }\end{array}$ \\
\hline 4 & $\begin{array}{l}\text { Jadi mauliate ma di hamu } \\
\text { amangboru dohot namboru } \\
\text { nami suang songoni dohot } \\
\text { bere nami saluhut na ala } \\
\text { nunga sada hamu mambahen } \\
\text { sada ulaon ima bere ku Jasmin } \\
\text { on tu tambak na timbo batu na } \\
\text { pir, au pe sai hu parate-atehon } \\
\text { dang dua hamu songoni sada } \\
\text { do hu bereng, au pe } \\
\text { humalateon do tu amanta } \\
\text { Debata dohot tu tondi } \\
\text { porbadia di dongani tondi } \\
\text { porbadia ma molo di adat } \\
\text { batak, apala tingkos songon } \\
\text { pandokan i nadiulahon na } \\
\text { parjolo.. }\end{array}$ & $\begin{array}{l}\text { So We would like to say thanks } \\
\text { to all of you the descendant of } \\
\text { our amangboru and namboru, } \\
\text { you have been united to uplift } \\
\text { the saring-saring of Jasmin to } \\
\text { tambak na timbo/batu na pir. I } \\
\text { have mentioned and I really } \\
\text { thanks to God and Holy spirit, } \\
\text { when you have done our } \\
\text { previous ancestors tradition } \\
\text { precisely }\end{array}$ & $\begin{array}{l}\text { Prestige expression is } \\
\text { clearly seen here, while } \\
\text { tulang Sidabutar deliver } \\
\text { their speech in laying the } \\
\text { ulos laman-laman at the top } \\
\text { of the skull's. It is actually a } \\
\text { confession from tulang } \\
\text { Sidabutar that hasuhuton } \\
\text { bolon has been success to } \\
\text { preserve their mangongkal } \\
\text { holi tradition, and } \\
\text { confession means a } \\
\text { prestigious. }\end{array}$ \\
\hline
\end{tabular}

\section{Conclusion}

In promoting Mangongkal Holi tradition, the indigenous oral tradition as a good effort in preserving, revitalizing local wisdom (thanksgiving, respect, responsibility, mutual cooperation, 
consensus in dialogue, and prestige) implied as batak toba's own identities; this tradition are potentially to be proposed as a global tradition/activities, since it can help to solve the lackness of cemetery land in Indonesia as well as in the world. Especially if the government could adopt and support the concept of rumah saring-saring (the House of Skull \& Skeleton) as found in St. Fransiskus Asisi, Pematangsiantar or Tugu Manihuruk, in Samosir island, (a simple but unique construction that can keep 21 corpses and save 700s skull/skeleton in it.

\section{Acknowledgemen}

The researchers express their thanksfulness to the Directorate General of Higher Education at Kemenristek DIKTI who had given the Doctoral's BPPs at the University of Sumatera Utara to the first writer of this article.

\section{References.}

[1] Miles, M., Huberman, M., and Saldana, J. 2014. Qualitative Data Analysis: A Methods Sourcebook. $3^{\text {rd }}$ Edition. Arizona: SAGE Publication.

[2] Sibarani, R. 2018. Batak Toba society's Local Wisdom of Mutual Cooperation in Toba Lake area; a linguistic anthropology. International Journal of Human Rights in Healthcare: 11th Ed. pp. 40-55: Emerald.

[3] Silalahi, CDM. 2016. Mangongkal Holi as the Highest Level of Tradition in Batak Toba Society. Journal Methoda, ISSN. 2088-9534. pp. 1-9: The Methodist University of Indonesia.

[4] Silalahi, CDM. 2016. Trilogy of Adat Laws in Mangongkal Holi: an ethical approach on Batak Toba Societies' communication. Journal of Education and Social Science (JESOC), ISSN. 2289.1552. Putra Jaya: Zes Rokman

[5] Simanjuntak, BA. 2007. Bungaran Antonius Simanjuntak: Kajian Antropologi Batak Prof BAS. Kompas Daily newspaper, May 3rd, 2007. In Aliansi Bangso Batak Toba, Unity of Bataknese in the World, March, 29th, 2017; www.bukan-tokohindonesia.blogspot.com/2009/06/bungaranantonius-simanjuntak-kajian.

[6] http://informasipedia.com/kependudukan/jumlah-penduduk-dunia/582-20-negara-berpendudukterbanyak-di-dunia-tahun-2015.html

[7] https://www.bps.go.id/publication/2018.download.html 